\title{
Board Structure, CEO Tenure, Firms' Charactersitics and Performance of Financial Institutions in Kenya
}

\author{
Nebert Mandala (MBA, CPAK, CPSK, CISA) \\ Prof. Erasmus Kaijage \\ Prof. Josiah Aduda \\ Dr. Cyrus Iraya (PhD), Senior Lecturer
}

School of Business, University of Nairobi, Kenya

Doi: 10.19044/esj.2017.v13n31p39 URL:http://dx.doi.org/10.19044/esj.2017.v13n31p39

\begin{abstract}
The broad objective of this research was to determine the effect of board structure on the performance of financial institutions in Kenya and also to find out what the intervening and mediating influence of the tenure of the CEO and firm's characteristics on this relationship might be. The specific objectives included; to examine the influence of board structure on performance of financial institutions in Kenya; to determine the intervening influence of CEO tenure on the association among board structure and performance of financial sector firms in Kenya; to examine the moderating effect of the firms' characteristics on the association among board structure and performance of financial institutions in Kenya; and to ascertain the joint effect of board structure, CEO tenure and firms' characteristics on performance. Secondary data was collected for a ten-year period from 2006 to 2015. Moderated and stepwise regression models and correlation analysis were adopted for the investigation of the association among the variables. The results showed that board structure had independent significant influence on performance of financial institutions; there was no significant intervening effect of CEO tenure on this relationship; there was a significant moderating effect of firms' characteristics on the relationship; and the joint effect of board structure, CEO tenure and firms' characteristics was significant. Through this study, the formulation of managerial policies and practices which will promote better governance practices and also appropriate the characteristics of firms and that will improve performance of financial institutions will be enhanced.
\end{abstract}

Keywords: Board Structure, CEO Tenure, Firms' Characteristics, Performance 


\section{Introduction}

Upsurge of boardroom tussles and corporate collapses have been witnessed in both developed economies like Commerce Bank (1991), Enron (2001), Adelphia (2002), HIH and World Com (2002) as well as in developing economies alike, such as Uchumi Supermarkets, East African Portland, CMC and Mumias Sugar Limited which are all in Kenya. Financial institutions in developing economies have also not been spared by the wave of corporate collapses and such collapses in the last three years have included Imperial Bank, Chase Bank, Dubai Bank, and National Bank of Kenya. In all of these, the members of the respective boards have been widely held responsible for the reduction in shareholders' wealth and most of these firms' failures. Most of fraud related cases that have led to the failure of major corporates have been attributed to the members of the board and management raising the question on the ability of members of the board to monitor managements of those firms. The various reforms and standards developed both in Kenya, and at the global level (such as the Sarbanes-Oxley Act in the United States) enhanced listing requirements including the Corporate Governance Code in Kenya, provide evidence of the need for strong governance structures. Most researches on corporate governance have been undertaken within developed economies; hence limited research exists in developing economies.

Financial institutions in Kenya are important for economic growth and development. They play a number of roles that would ensure micro and macro-economic growth and development. Generally, the assumption has been that the board dynamics of non-financial firms equally work for financial institutions. There is growing recognition that financial institutions board dynamics is different due to the broader responsibilities on directors and the regulatory regimes. Therefore, governance cannot be generalized across all companies. Furthermore, extant literature has provided evidence that corporate governance in itself is not static, but rather dynamic and emergent. It is on this basis that their performance continues to be a key concern to the management practitioners and researchers. The choice of the optimal board structure would be a panacea to the improvement of strategic choices yielding to better performance (Kajola, 2004). In the years 2012 and 2013 alone, Kenyan Banks, being the most critical player in the financial sector, unveiled new chief executives and thereby raised several questions regarding the rate of CEO turnover. This further caused researchers as well as practitioners to raise questions relating to the effect of CEO tenure on performance and whether the CEO turnover would sustain growth in the years ahead.

Empirical evidence has yielded mixed and contradictory results on the optimal board structure (Dalton et al., 1998). However, most agree on the 
important variables representing board structure and that may have an impact on the monitoring and thus performance. The debate about influence of board structure on the profitability of a firm continues, given that prior research has yielded conflicting results (Dalton et al., 1998) suggesting that other factors mediate or intervene to the acceleration of the relationship. Firms' characteristics and CEO tenure could be some of the factors that come into play. A number of studies have established negative relationship among the CEO turnover, CEO tenure, and firms' performance (Murphy \& Zimmerman, 1993; Weisbach, 1988). Furthermore, studies have shown that firms undergoing transition in emerging economies have higher degrees of ownership concentration which are associated with the firms' corporate governance, financing, and investment policies. Ownership of most firms is distributed among institutional investors and retail investors; with ownership concentrated mainly to institutional investors (Shleifer \& Vishny, 1997). The ownership can also be categorized into state ownership and public ownership. The type of ownership structure of a firm ultimately affects the board structure categorized in this study as type 1 board, whose members directly own equity shares in the firm; type 2 board, where the board members do not hold any equity shares in the firm whose board they sit on; and type 3, which is a blend between the two extremes, where some members own equity shares and some do not hold any equity shares.

Studies have concentrated on understanding how board structure as a variable of corporate governance affects performance of firms. Whenever there is an agency conflict among the various relationships in the firm, corporate governance has the ability of influencing a firm's performance. In the management-shareholder conflict, the agency problem is often manifested in management's self-interest. In the controlling-minority shareholder conflict, on the other hand, shareholders with controlling power tend to employ these powers to expropriate. The main cause of these two sets of conflicts is as a result of the managers in the first case and the controlling shareholders in the second case receiving only a portion of the firm's earnings, while they fully appropriate the resources diverted.

In view of the above, it can be concluded that empirical studies which have been conceptualized along the influence of either the CEO tenure and or firms' characteristics regarding the effect of board structure on performance in developing countries are rare. Prior research in the field of corporate governance has majorly focused on its best practices among developed countries (e.g., Dahya \& McConnell, 2007; Wintoki et al., 2012). It is notable that a number of institutional factors regarding newlyindustrialising countries are quite different and therefore this study shifts to a new setting where it examines the impact of board structure, CEO tenure, and firms' characteristics on firms' performance. 
Empirical studies on board structure and performance have demonstrated that the relationship is quite equivocal and does not reveal any conclusive relationship (Dalton \& Daily, 1999). Board structure variables studies include size, diversity, CEO duality, busyness, and composition among others. However, no evidence has been found that board type as defined in this study has been used as a variable. The question remains as to the casual relationship between these variables. There is need to depart from traditional board structure variables and attempt construction of a new and comprehensive theoretical model, which would cover all the emerging issues in the board structure and close the gap.

\section{Research Objectives}

The general objective of this research was to determine whether a relationship existed among board structure, CEO tenure, firms' characteristics, and the performance of financial institutions in Kenya.

The specific objectives were:

i) To determine the effect of board structure on performance of financial institutions in Kenya.

ii) To establish the intervening effect of CEO tenure on the relationship between board structure and performance of financial institutions in Kenya.

iii) To find out the moderating effect of firms' characteristics on the relationship between board structure and performance of financial institutions in Kenya.

iv) To ascertain the joint effect of board structure, CEO tenure, and firms' characteristics on performance of financial institutions in Kenya.

\section{Literature Review \\ Theoretical Review}

Scholars and governance practitioners agree that there is a more "varied and complex" association among the board structure and performance than can be dealt with in each individual governance theory (Nicholson \& Kiel, 2007). Neither the general model nor the links between the two variables can be fully explained by a single theory. The conceptualization in this study is supported by the agency, the upper echelon, the convergence of interests, the entrenchment, and stewardship theories.

\section{Agency Theory}

In general, the starting point for any corporate governance debate is the principal agent theory (Anthony \& Biekpe, 2002). "Modern society and private property" by Berle and Means (1932), described in their classical research, is the theoretical basis of most research studies in governance. The 
agency's theory describes the most relevant agency issues in today's institutions, particularly since separation of ownership and control exist. Modern companies suffer from control and ownership separation, as they are managed by professionals who are not owners. Empirical evidence to explain both the nature of these agency problems and how to settle them has been documented by Jensen and Meckling's (1976) fundamental work through proposing the theory of the firm which is based on conflicts of interest among the stakeholders involved, equity holders, executives and debt holders. Empirically and theoretically, the finance theory has been developed to enable a thorough examination of the issues caused by the divergence of interests among business managers and equity owners.

This view is consistent with the principle-agent paradigm. To this end, ensuring management considers shareholder interests of reducing costs related with the agent's conflict is a key issue. Consequently, managers are faced with a number of issues: first, is how to select the appropriate professionals (managers). Second, is a moral hazard problem, which allows managers the proper incentives of making efforts and decisions that are aligned with equity holders' interests (Antonio \& Biekpe, 2002). The theory of the agency justifies the propensity of advice dominated by outsiderdominated boards (Eisenhardt, 1989; Jensen \& Meckling, 1976). Given that contemporary firms have separated ownership and control, it creates moral hazard problems among management and the owners. There is a likelihood that the former may exploit the information they have for their own selfish reasons that may result in damage of the owners' interests. In addition, the theory is in support of separating positions of the board chairperson and CEO or else agency costs become enhanced. Especially if the chairman controls the CEO, then the company experiences financial and market control (Balta, 2008). In corporate governance, the main disadvantage of agency theory is that it only focuses on the equity holders' goals, thus locking out other subjects in firm management and operation. This theory helps to determine the variables of the study, the organizational characteristics and structure of the board of the company due to the support of lean boards dominated from the outside and the theory of the property rights of the company. The theory is also relevant for studying the separation of control property and it also creates a conflict that can be managed through the structure of the board.

\section{Convergence-of-interests Theory}

The agency's conflict can be resolved by promoting the ownership of equity among the directors in an attempt to align their interests with those of equity holders. The theory of convergence of interests assumes that in cases where the board does not participate in share ownership, they become selfsufficient, but possess petite power to maneuver controls that have been put 
in place. Hence, guarantees equity holders' interests are considered. Mechanism of the corporate governance in this case includes the existence of independent members of the board who have shown to cause less manipulation of fraud and earnings (Beasley et al., 2000; Klein, 2002). Increased share ownership by directors compels them to keep the equity holders' interests in mind when making decisions (Jensen \& Meckling, 1976; Beasley, 1996).

As share ownership increases, managers are more likely to take steps that will lead to the aligning of their interests with those of equity holders. Increasing the decision-making quality improves harmonization of actual cash flows with profits, i.e. increasing the quality of earnings. Executives become more aware, engage in less fraud, and get less motivated to deliberately manipulate profits to improve performance from what it is. In short, when employees have share ownership, they behave like unique owners; every action they undertake against the interest of company ends up hurting them. At this point, governance mechanism wouldn't be needed (Teresa \& Giuseppe, 2011). This theory helps the researcher to develop the board type as a fundamental feature of the board's structure variable and using postulations of the theory proceeds to categorize it into three types.

\section{Entrenchment Theory}

Morck et al. (1988), contrary to the theory of convergence of interests, developed entrenchment theory that alludes to a negative relationship among profitability and board share ownership. "Entrenchment theory" says that higher levels of ownership reduce business performance. This agrees with the logic that maximizing market share and technology leadership rather than maximizing profits is attributed to managers who own significant levels of shares. The involvement of the board members also has a negative influence on the value of the company (Dwivedi \& Jain, 2005).

The entrenchment theory has similar conclusions on employees at extremely low as well as extremely high levels of capital. At low levels of share ownership, employees do not consider equity holders' interests; however, they are so scarce that they lack the power to subvert the governance arrangements. With high levels of shares ownership, executives or directors are shareholders; as such, inadequate actions maybe be damaging themselves. It is, in essence, the average range of the equity holding that tends to differ. When managers or principal altogether get a relatively high share of equity (but not the extreme levels of ownership that aligns their interests with shareholders), can they have enough to maneuver controls (Fama \& Jensen, 1983)? This theory helps the researcher to develop the board type as a fundamental feature of the board's structure variable. 
Entrenchment theory allows executives to act on their own interests without major fears of elimination or sanctions; since they could "shut up". Previously, other studies have shown that this phenomenon may occur at relatively low levels of absolute ownership (Morck et al., 1988). If the degree of integration exists, it should reflect on poor quality of income. The poor quality of profits shows that managers may intentionally manipulate profits, exclude and commit bad decisions, or carry out fraudulent activities that reduce profits. All of these activities imply that actual cash flows vary from the benefit projects should provide as cash flows. In cases where the theory aligned, a strategy for the institutions could have included providing equity ownership to the employees and members of the board, which would enhance control measures within the depth range. Therefore, it is important to know where there might be thresholds inside as well as outside the range and whether the governance mechanisms can overcome the integration process.

\section{Stewardship Theory}

In Stewardship theory, it is argued that agents are motivated by both individual goals and the principal's interest (Davis et al., 1997; Donaldson \& Davis, 1991). This theory therefore shows that independent external board members are not necessarily motivated by their own goals and thus excludes them from being agents, but makes them the best managers of their companies (Davis et al., 1997). This theory, however, supports the principle of CEO's duality. Only when there is CEO duality can the power of executives and the best management duty be exercised (Donaldson \& Davis, 1991). It also explains the importance of internal directors. The proponents of the theory believe that CEO-chairperson duality leads to strengthened leadership coupled up with internal effectiveness. The firm will have one voice speaking on its behalf and disagreements between the CEO and the board's chairperson are avoided (Davis, Schoorman \& Donaldson, 1997). Stewardship theorists agreed with this conclusion calling it CEO duality and stating that it improved organizational leadership efficacy. This is, however, in contrast to agency theorists, who are in support of separating the CEO and Chairman roles in order to promote proper checks on management. Various studies have concluded that the association among CEO-chairperson duality and performance of a firm is disputed and ambiguous.

Stewardship theory states that the board's key function is to basically advise and put managerial steps in place in order to discipline and monitor, a vision that is considered diametrically opposed to agency theory. This theory states that the association among board of directors' composition and the company's profitability is possibly due to advice provided by external directors instead of its monitoring and control activities (Anderson \& Reeb, 
2004). The theory is important to this study as it shows the value of board structure and ensures that managerial behavior is aligned with principle's interests and therefore enhances performance. Through the theory, CEO duality is identified as one of the variables of board structure in order to empirically test its impact on performance. The theory also further guides the conceptualization of CEO tenure as having a likely significant intervening effect on the association among board structure and institutional performance.

\section{The Upper Echelons Theory}

CEO tenure, which is the moderating variable of this study, is anchored on this theory. The theory was developed by Hambrick and Mason (1984). The theory posits that organizational performance and strategic choices are partially provided by top management demographics. It suggests that managerial decisions do not always follow rational reasons, but are largely influenced by the natural limits of executives as human beings (Nielsen, 2010).

The theory suggests that senior management demography includes age, education, functional background, and financial positions. Other researchers also included tenure (Nielson \& Nielsen, 2013) and gender (Marimuthu \& Kolandaisamy, 2009) as part of the demographic elements of senior management. Therefore, the study is based on the fact that the managing director is part of the upper echelon; his mandate will influence his strategic choices and, consequently, the performance of the institution. The theory developed the proposition that the long-term CEO seemed to propose towards the status quo and would be reluctant to implement change strategies (Nielsen, 2010). An organization that has a managing director with different holding benefits from the different experiences and perspectives brought by the single CEO and this has a positive influence on performance.

Supporters of the upper echelon theory said companies with younger managers were more prone to risk strategies than older managers and that organizations with younger managers might experience growth and profitability. This position was supported by other researchers who argued that younger managers tend to be related to organizational performance since they were ready to change. The theory also developed the proposition that the long-time managing director seemed to be pushing for the status quo and would be reluctant to implement change strategies (Nielsen, 2010). An organization that has a managing director with different holding, benefits from the different experiences and perspectives brought by the single CEO and this has a positive impact on performance.

The theory proposals have given rise to significant literature in the investigation of the role of CEOs, their holding, and their performance in the 
company. The theory has implications for the study as it helps to formulate the research hypothesis that the CEO's tenure and mandate plays a major role in the association among board structure and institutions' profitability. Apparently, the theory still requires empirical data, especially in different contexts. The importance of top management, as posed by theory, implies that the CEO's combination of mandates with other variables in this study is needed to prove the basis of this theory. This theory has guided the conceptualization of the influence of CEO tenure on the conduct of financial institutions in Kenya.

\section{Empirical Review}

Ongore (2011) indicates that the board of directors only cannot be a solution to all governance problems. His findings show that research on ideal corporate governance structures should pay inordinate attention to the board's omission of some other likewise essential aspects of governance like ownership structure. The risk-taking orientations of their equity holders directly influence the decisions of management regarding investment (Shleifer \& Vishny, 1994). Organizational characteristics including structures of ownership manifest themselves in governance of organizations differently.

The empirical literature on the variables of the study, board structure, CEO tenure, firms' characteristics and firms' performance as conceptualized in this study are rare. Studies that have looked at the variables' direct relationships have reported inconclusive results, for instance the works of Yermack (1996); Klapper and Love (2002); Gompers et al. (2003); and Black et al. (2003). The scholars did not record any significant association among the "best practices" in corporate governance and profitability. Additionally, Coles et al. (2008) argued that board structure is not relevant in the study of CEO and organizational profitability.

Coles et al. (2008) studied the relationship among governance including structure of the board and profitability of the firm. There exists a positive association among concentration of ownership and performance. Further research on the CEO's payment, term in the office, and profitability association include the studies of Jensen and Murphy (1990) and Dalton et al. (1998). These scholars have concluded on board composition, financial skills of the board, and CEO duality, as the main components of corporate governance. Johl et al. (2015) noted that a good corporate governance framework incorporates ownership concentration, directors' equity ownership and the board structure, CEO tenure, and directors' remuneration. 


\section{Research Gaps}

Research on members of the board has originally been centered on the association among the structure of the board and profitability of the firm. Previous studies have not shown a conclusive association among the structure of the board and profitability (Dalton \& Daily, 1999). Therefore, further research should be done on other areas of the board. This conclusion is in agreement with conclusions by Johnson, Daily and Ellstrand (1996). The process of the board could be the absent connection. Generally, the process of the board refers to the decisive action of the board (Zahra \& Pearce, 1989). Anderson and Anthony (1988) concluded that the process of the board refers to the good and meticulous discussions of issues affecting the firm so as to make appropriate decisions and follow them through.

Variables of structure of the board, which were studied, included size of the board, CEO duality, board business, and composition of the board among others. However, no evidence has been found that board type has been widely used as a variable. A research gap exists as to how board members with a financial stake in the firm are likely to impact on financial performance. The question remains as to the casual relationship between these variables. There is need to depart from traditional board structure variables and attempt construction of a new, comprehensive theoretical model, which would cover all of the emerging issues in the board structure and close the gap.

Further research should introduce a consolidative concept model among structure of the board and its performance, with process of the board as an intervening variable. Only recently has literature on the process of the board have become available. Given that it is not easy to access boards of organizations, this could be the factor contributing to insufficient research on the process of the board (Zahra \& Pearce, 1989). Contrary to this, the researcher believes that such a limitation should not excuse lack of development of a working model for conceptual analysis. 
Table 2.1. Summary of Research Gaps

\begin{tabular}{|c|c|c|c|c|}
\hline Author(s) & Focus of the Study & Findings & Research Gaps & Bridging the gaps in the proposed study \\
\hline Daily and Dalton (1993) & $\begin{array}{l}\text { To examine the influence of CEO } \\
\text { duality on financial performance of } \\
\text { institutions. }\end{array}$ & $\begin{array}{l}\text { No relationship with financial } \\
\text { performance. }\end{array}$ & $\begin{array}{l}\text { The study used ROA, ROE, P/E ratio as } \\
\text { the performance indicators. }\end{array}$ & $\begin{array}{l}\text { Sales growth has been introduced as a } \\
\text { performance indicator. }\end{array}$ \\
\hline Vance (1995) & $\begin{array}{l}\text { To examine the influence of Insiders vs } \\
\text { Outsiders on performance of firms. }\end{array}$ & $\begin{array}{l}\text { Executive directors' representation had a } \\
\text { positive relationship with financial } \\
\text { performance. }\end{array}$ & $\begin{array}{l}\text { The study only focused on two board } \\
\text { structure variables. }\end{array}$ & $\begin{array}{l}\text { The study focuses on a number of board } \\
\text { structure variables. }\end{array}$ \\
\hline Anthony et al. (2002) & $\begin{array}{l}\text { To examine the influence of the size of } \\
\text { the board, independence and CEO } \\
\text { duality on profitability operationalized } \\
\text { by ROA, Tobin's q, and Growth in } \\
\text { revenue of non-financial listed firms on } \\
\text { the GSE. }\end{array}$ & $\begin{array}{l}\text { The governance structures studied the } \\
\text { impacts of the profitability of Ghanaian } \\
\text { Organizations. }\end{array}$ & $\begin{array}{l}\text { The commercial banks and other } \\
\text { financial institutions were not included } \\
\text { in the research consistent with other } \\
\text { studies because of their huge debt } \\
\text { structures. }\end{array}$ & $\begin{array}{l}\text { The study focused on the financial } \\
\text { institutions. }\end{array}$ \\
\hline Bonazzi and Islam (2007) & $\begin{array}{l}\text { To design a model to find a solution for } \\
\text { an on-going problem in financial } \\
\text { economics: how can CEOs be } \\
\text { efficiently supervised by the members } \\
\text { of the board? }\end{array}$ & $\begin{array}{l}\text { The design of the model focused on } \\
\text { identifying an optimal level of control } \\
\text { and monitoring, which maximizes } \\
\text { equity share value, to guide the board of } \\
\text { directors. }\end{array}$ & $\begin{array}{l}\text { The model was limited as it does not } \\
\text { speak of the input of other board } \\
\text { members and it is focused mainly on the } \\
\text { monitoring function, despite the fact that } \\
\text { the boards also play vital } \\
\text { responsibilities. }\end{array}$ & $\begin{array}{l}\text { The effects of individual governance } \\
\text { variables were studied. }\end{array}$ \\
\hline $\begin{array}{l}\text { Benjamin Ehikioya } \\
\text { (2007) }\end{array}$ & $\begin{array}{l}\text { To determine the relationship among } \\
\text { corporate governance structure and } \\
\text { performance of institutions in Nigeria. }\end{array}$ & $\begin{array}{l}\text { Ownership concentration positively } \\
\text { affects performance. Although the } \\
\text { findings do not provide evidence to } \\
\text { support the influence of board } \\
\text { independence on performance, there is } \\
\text { significant evidence to prove the fact } \\
\text { that CEO duality unfavorably influences } \\
\text { firm performance. }\end{array}$ & $\begin{array}{l}\text { The research relied a lot on publicly } \\
\text { accessible data for a sample of more } \\
\text { than } 100 \text { Nigerian listed organizations } \\
\text { from } 1998 \text { to } 2002 \text { and focused on } \\
\text { corporate governance variables. }\end{array}$ & $\begin{array}{l}\text { The study included non-listed firms to get } \\
\text { more insights into the variables. The study } \\
\text { introduces board type as a new variable for } \\
\text { board structure and measures CEO tenure. }\end{array}$ \\
\hline Jackling and Johl (2009) & $\begin{array}{l}\text { To examine the association among } \\
\text { internal governance structures and } \\
\text { performance companies in India. }\end{array}$ & $\begin{array}{l}\text { The research findings are in agreement } \\
\text { with facets of agency theory as a higher } \\
\text { ratio of non-executive directors } \\
\text { increased profitability. }\end{array}$ & Thesis adopted an exploratory design. & $\begin{array}{c}\text { The study adopts a multiple regression } \\
\text { analysis. }\end{array}$ \\
\hline Tatyana Sokolyk (2010) & $\begin{array}{l}\text { To investigate the influence of } \\
\text { governance provisions on forced CEO } \\
\text { exit due to inappropriate acquisitions. }\end{array}$ & $\begin{array}{l}\text { CG provisions have no effect on } \\
\text { probability of forced CEO exit } \\
\text { following inappropriate acquisitions. }\end{array}$ & $\begin{array}{l}\text { The effect of the CEO tenure is not } \\
\text { considered. }\end{array}$ & $\begin{array}{c}\text { CEO tenure was studied alongside the } \\
\text { turnover. }\end{array}$ \\
\hline
\end{tabular}




\begin{tabular}{|c|c|c|c|c|}
\hline Afzalur Rashid (2011) & $\begin{array}{l}\text { This research set out to examine board } \\
\text { independence and the effect of } \\
\text { Independence of board structure on } \\
\text { profitability of organizations in } \\
\text { Bangladesh. }\end{array}$ & $\begin{array}{l}\text { The finding of the research is in support } \\
\text { of the agency theory, but negates the } \\
\text { stewardship theory suggesting that the } \\
\text { non-executive directors and combined } \\
\text { leadership role do not increase } \\
\text { profitability. }\end{array}$ & $\begin{array}{c}\text { The data was obtained from the } \\
\text { observation of different corporations } \\
\text { while ignoring underlying } \\
\text { organizational differences. }\end{array}$ & $\begin{array}{l}\text { The study focused on a specific industry of } \\
\text { the financial services sector. }\end{array}$ \\
\hline Michael Adusei (2011) & $\begin{array}{c}\text { To determine the association among } \\
\text { board structure and profitability of } \\
\text { Ghanaian banks. }\end{array}$ & $\begin{array}{l}\text { The results indicate that reduced board } \\
\text { size enhances performance, and } \\
\text { composition of the board has an } \\
\text { insignificant negative correlation with } \\
\text { profitability. }\end{array}$ & $\begin{array}{c}\text { The study focuses only on two board } \\
\text { variables. }\end{array}$ & $\begin{array}{l}\text { The effect of many variables was studied } \\
55 \mathrm{rfv} \text {. }\end{array}$ \\
\hline Teresa and Joseph (2011) & $\begin{array}{l}\text { To determine the association among } \\
\text { board share ownership and CG on } \\
\text { profitability of corporations. }\end{array}$ & $\begin{array}{l}\text { Conclusion is in agreement with } \\
\text { entrenchment theory. Both independent } \\
\text { and insider boards become entrenched, } \\
\text { negatively profitability and CG structure }\end{array}$ & $\begin{array}{c}\text { It's not clear how profitability is } \\
\text { affected by individual governance } \\
\text { variables. . }\end{array}$ & $\begin{array}{l}\text { The effect of individual governance variables } \\
\text { was studied. }\end{array}$ \\
\hline Letting et al. (2012) & $\begin{array}{l}\text { Diversity of the board and profitability } \\
\text { of firms in NSE. }\end{array}$ & $\begin{array}{l}\text { The findings provide evidence of a weak } \\
\text { positive association among profitability } \\
\text { and diversity of the board. }\end{array}$ & $\begin{array}{c}\text { The study was limited to firms listed at } \\
\text { the NSE and only to members of the } \\
\text { Board. }\end{array}$ & $\begin{array}{l}\text { The study included CEO tenure and is } \\
\text { contextualized in FIs including non-listed } \\
\text { firms. }\end{array}$ \\
\hline Kamaara et al. (2013) & $\begin{array}{l}\text { The relationship between BoD } \\
\text { characteristics and performance of } \\
\text { commercial SCs in Kenya. }\end{array}$ & $\begin{array}{c}\text { There is a strong association among } \\
\text { board composition/ characteristics and } \\
\text { performance of commercial SCs in } \\
\text { Kenya. }\end{array}$ & $\begin{array}{c}\text { The study was limited to only } \\
\text { commercial SCs in Kenya and studied } \\
\text { BoD characteristics only. }\end{array}$ & $\begin{array}{l}\text { The study included CEO tenure and is } \\
\text { contextualized in FIs including Commercial } \\
\text { and nonprofit making. }\end{array}$ \\
\hline Akbah Ahsan (2015) & $\begin{array}{l}\text { The role of CG mechanisms in firm } \\
\text { profitability optimization in Pakistan. }\end{array}$ & CG significantly increases profitability. & $\begin{array}{l}\text { The study was limited to developing a } \\
\text { conceptual model. }\end{array}$ & The study undertook an empirical analysis. \\
\hline $\begin{array}{c}\text { Bhatt R. R. and } \\
\text { Bhattacharya S. (2015) }\end{array}$ & $\begin{array}{l}\text { Board structure and profitability of } \\
\text { Indian IT organizations. }\end{array}$ & $\begin{array}{l}\text { The study, after controlling for firm- } \\
\text { specific factors, shows that larger sizes } \\
\text { of the board positively influenced firms' } \\
\text { performance. The research failed to find } \\
\text { any association among the number of } \\
\text { board meetings and firms' performance. } \\
\text { However, attendance at other events by } \\
\text { the board of directors was found to be } \\
\text { positively related to firms' performance. }\end{array}$ & $\begin{array}{c}\text { The study ignored intervening and } \\
\text { moderating effects of any other } \\
\text { variables. }\end{array}$ & $\begin{array}{c}\text { The study included CEO tenure and firms' } \\
\text { characteristics as intervening and moderating } \\
\text { variables. }\end{array}$ \\
\hline $\begin{array}{l}\text { Johl S.K, Kaur S., and } \\
\text { Cooper B.J. (2015) }\end{array}$ & $\begin{array}{l}\text { Determine the effect of board } \\
\text { characteristics on profitability. The } \\
\text { study focuses on effects of board } \\
\text { meeting, board composition, size of the } \\
\text { board and directors accounting } \\
\text { expertise on firm accounting }\end{array}$ & $\begin{array}{l}\text { Concluded that board independence has } \\
\text { no effect on profitability. Whereas size } \\
\text { of the board and its financial expertise } \\
\text { positively affect profitability. Board } \\
\text { diligence, that is meetings, positively } \\
\text { affects profitability. }\end{array}$ & $\begin{array}{l}\text { The study ignored intervening and } \\
\text { moderating effects of any other } \\
\text { variables. }\end{array}$ & $\begin{array}{c}\text { The study included CEO tenure and firms' } \\
\text { characteristics as intervening and moderating } \\
\text { variables. }\end{array}$ \\
\hline
\end{tabular}




\begin{tabular}{|c|c|c|c|c|}
\hline & performance. & & & \\
\hline $\begin{array}{l}\text { Wah K. K., Shafie M. Z., } \\
\text { and Kamilah A. (2015) }\end{array}$ & $\begin{array}{l}\text { Determine the influence of corporate } \\
\text { governance practices on firms' } \\
\text { Performance. }\end{array}$ & $\begin{array}{l}\text { The result showed that board size has } \\
\text { significantly weak negative relationship } \\
\text { with ROA, but it was found to be } \\
\text { insignificant to ROE. The other finding } \\
\text { indicated that there was no significant } \\
\text { association among board independence } \\
\text { and performance of institutions. }\end{array}$ & $\begin{array}{c}\text { The study ignored intervening and } \\
\text { moderating effects of any other } \\
\text { variables }\end{array}$ & $\begin{array}{c}\text { The study included CEO tenure and firms' } \\
\text { characteristics as intervening and moderating } \\
\text { variables. }\end{array}$ \\
\hline Zona Fabio (2016). & $\begin{array}{c}\text { Agency models in various stages of the } \\
\text { CEO's term: The influence of } \\
\text { managerial share options and } \\
\text { composition of the board on R\&D } \\
\text { investment. }\end{array}$ & $\begin{array}{l}\text { Combining the two agency models of } \\
\text { limited competence and managerial } \\
\text { opportunism, the conclusion is that } \\
\text { governance variables affect CEO's term } \\
\text { differently in the early and later stages. } \\
\text { Earlier, R\&D investment is reduced by } \\
\text { stock options and board independence; } \\
\text { whereas in later stages, these effects } \\
\text { reversed. }\end{array}$ & $\begin{array}{l}\text { The study is limited to US firms where } \\
\text { corporate governance is well developed. }\end{array}$ & $\begin{array}{c}\text { The study used data from a developing } \\
\text { country, Kenya, to determine how } \\
\text { profitability is affected by the structure of the } \\
\text { board. }\end{array}$ \\
\hline $\begin{array}{c}\text { Gurusamy Palaniappan } \\
\text { (2017) }\end{array}$ & $\begin{array}{c}\text { To examine Board Characteristics, } \\
\text { Audit Committee, and Ownership } \\
\text { Structure effect on Performance of } \\
\text { institutions. }\end{array}$ & $\begin{array}{l}\text { Board size has a significant positive } \\
\text { effect on profitability, ROA and ROE. } \\
\text { Audit committee independence is } \\
\text { significant and negatively affected by } \\
\text { ROE. The same promoters' shareholding } \\
\text { is negatively and significantly } \\
\text { associated with all the financial } \\
\text { measures and there is a significant } \\
\text { negative association among institutional } \\
\text { shareholding and financial performance } \\
\text { (Tobin's Q and ROA). }\end{array}$ & $\begin{array}{l}\text { The study ignored intervening and } \\
\text { moderating effects of any other } \\
\text { variables. }\end{array}$ & $\begin{array}{c}\text { The study included CEO tenure and firms' } \\
\text { characteristics as intervening and moderating } \\
\text { variables. }\end{array}$ \\
\hline
\end{tabular}




\section{Conceptual Framework}

The conceptual model has integrated the theories of agency, entrenchment, and convergence of interests to present a conceptualised interaction among board structure (independent variables) and institutional performance (dependent variables). A discussion of the dependent, independent, moderating, and intervening variables is undertaken followed by the conceptual model and the research hypotheses. The model further conceptualizes CEO tenure as intervening, while firms' characteristics were placed as moderating in the relationship. This position is depicted in hypothesis two and three in the diagram. Finally, the model tests the joint effect of the three variables on performance in hypothesis four. This proposition has not been previously tested to the best knowledge of the researcher. The model postulates that since the ownership is separated from control, the agent could be motivated by selfish reasons. The structure of the board and its effectiveness provides an essential controlling function in an effort to address the agency conflict that exists among the management and equity holders. Figure 2.1 shows the conceptual framework for this study.

Figure 2.1. Conceptual Model

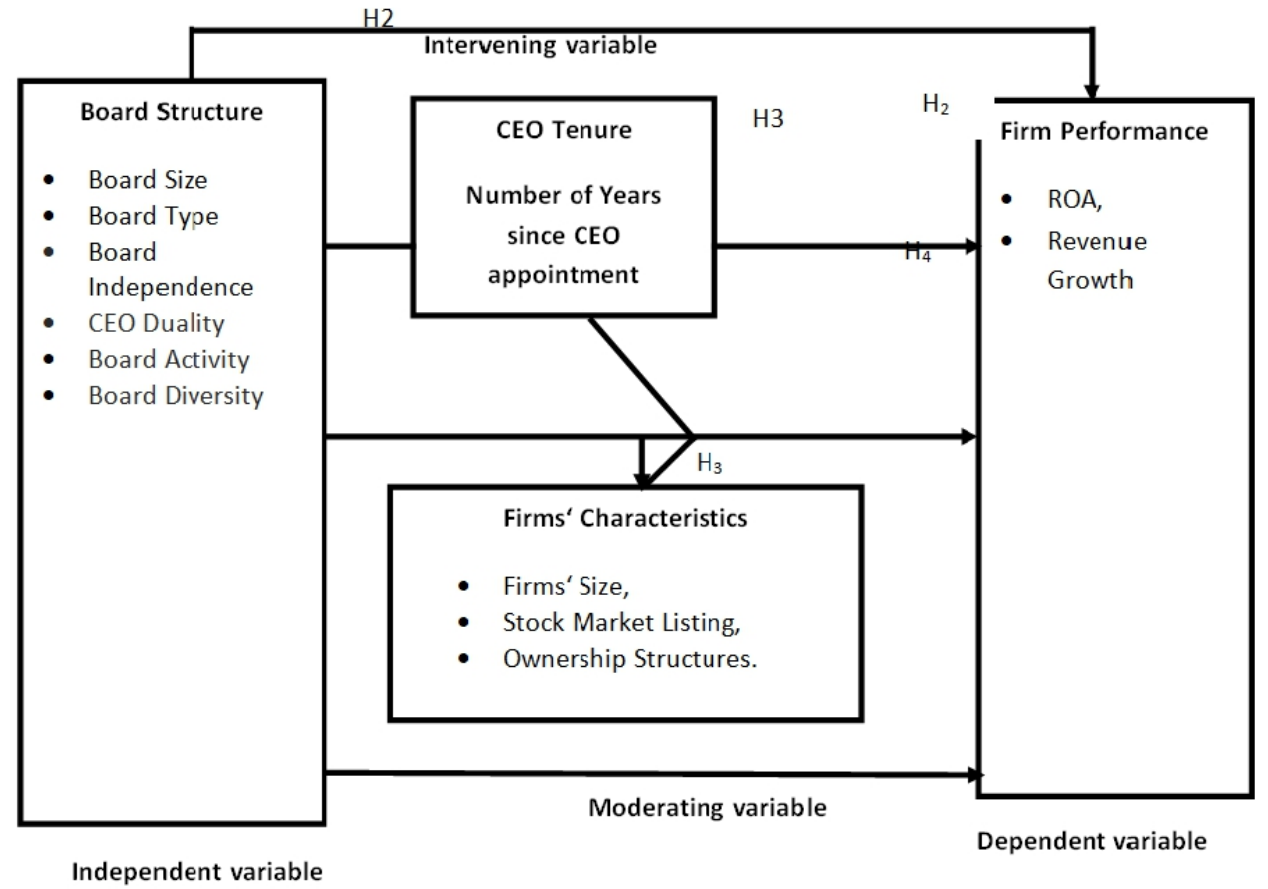

\section{Hypothesis of the Study}

From the above conceptual model, the following four hypotheses were formulated and tested: 
$\mathbf{H}_{\mathbf{0 1}}$ : There is no significant effect of board structure on performance of financial institutions in Kenya.

$\mathrm{H}_{\text {o2: }}$ There is no significant intervention effect of CEO tenure in the relationship between board structure and performance of financial institutions in Kenya.

$\mathbf{H}_{\mathbf{0} 3:}$ There is no significant moderation effect of firms' characteristics in the relationship between board structure and performance of financial institutions in Kenya.

$\mathbf{H}_{\mathbf{0} 4:}$ There is no significant joint effect of board structure, CEO tenure and firms' characteristics on performance of financial institutions in Kenya.

\section{Methodology}

\section{Research Design, Data, and Sampling}

Using data from a developing country, Kenya, a correlational research design was developed. The data required was collected for a tenyear period from 2006 to 2015 for the institutions that were sampled from the financial sector in Kenya through data collection sheets from annual reports and company websites. The population of the research was 3,989 financial institutions in Kenya comprising 5 regulators, 43 commercial banks, 10 Investment banks, 2 development banks, and 1 mortgage finance company, 41 insurance companies, 9 deposit taking micro-finance institutions, and 3,887 Sacco's (http://www.centralbank.go.ke). The study followed the simple stratified random sampling in obtaining viable data sets and sampled 98 firms from all the categories.

\section{Operationalization of Study Variables}

The study used ROA to measure performance. Consistent with Rashid and Lodh (2008), the research computed ROA using EBIT scaled by the book value of total assets. It used multi variables to represent the board structure. This comprised of the size, composition, activity, diversity, CEO Duality, and type. Board size was adopted because it has several consequences of how the board functions and hence the performance of the organizations (Coles et al., 2008). Board independence also referred to as composition (BDCOM) in this research referred to the ratio of outsiders or independent members of the board, who are not involved in the operations of the institutions consistent with the studies by Gurasamy (2017). The CEO duality is when the chairperson occupies the CEO position too. In line with several studies, Daily and Dalton (1994), the CEO duality was a binary. However, it is described as a variable of the duality of the CEO, which was equal to zero if the CEO position was held by the same person as the chairman, otherwise one. 
Table 3.2. Operationalization of Variables

\begin{tabular}{|c|c|c|c|c|}
\hline Variable & $\begin{array}{c}\text { Type of } \\
\text { Variable }\end{array}$ & Indicator & Operationalization & Literature \\
\hline \multirow[t]{6}{*}{ Board Structure } & \multirow[t]{6}{*}{ Independent } & Board Size (BS) & $\begin{array}{l}\text { The natural logarithm of the } \\
\text { total board members-NBM }\end{array}$ & $\begin{array}{c}\text { Coles et al., 2008; } \\
\text { Zahra and Pearce, } \\
1989\end{array}$ \\
\hline & & $\begin{array}{c}\text { Board } \\
\text { Composition } \\
\text { (BC) }\end{array}$ & $\begin{array}{c}\text { Ratio of non-executive board } \\
\text { members to the total } \\
\text { members of the board- } \\
\text { NIDOB }\end{array}$ & $\begin{array}{c}\text { Kamaara, Gachunga } \\
\text { and Waititu (2013) }\end{array}$ \\
\hline & & $\begin{array}{l}\text { CEO Duality } \\
\text { (CEOD) }\end{array}$ & $\begin{array}{c}\text { Dummy: Value zero (0) } \\
\text { where CEO duality exists \& } \\
\text { one (1) for otherwise. - } \\
\text { CEOCP }\end{array}$ & $\begin{array}{l}\text { Daily and Dalton } \\
\text { (1994) }\end{array}$ \\
\hline & & $\begin{array}{l}\text { Board Activity } \\
\text { (BA) }\end{array}$ & $\begin{array}{l}\text { Number of meetings and } \\
\text { other activities-NBMeet }\end{array}$ & $\begin{array}{l}\text { Letting, Aosa and } \\
\text { Machuki (2012) }\end{array}$ \\
\hline & & $\begin{array}{l}\text { Board Diversity } \\
\text { (BD) }\end{array}$ & $\begin{array}{l}\text { Proportion of female } \\
\text { members of the board to the } \\
\text { total board members - } \\
\text { NfmDOB }\end{array}$ & $\begin{array}{l}\text { Letting, Aosa and } \\
\text { Machuki (2012) }\end{array}$ \\
\hline & & $\begin{array}{c}\text { Board Type } \\
\text { (BT) }\end{array}$ & $\begin{array}{l}\text { Type } 1,2 \text { and } 3 \text { as defined in } \\
\text { the study-NDOES-PDTEH }\end{array}$ & $\begin{array}{c}\text { Teresa and Joseph, } \\
\text { (2011) }\end{array}$ \\
\hline \multirow[t]{2}{*}{$\begin{array}{c}\text { Firms' } \\
\text { Performance }\end{array}$} & \multirow[t]{2}{*}{ Dependent } & $\begin{array}{c}\text { Return on } \\
\text { Assets (ROA) }\end{array}$ & EBIT/TA & \multirow[t]{2}{*}{$\begin{array}{l}\text { Rashid and Lodh } \\
\text { (2008) }\end{array}$} \\
\hline & & $\begin{array}{l}\text { Revenue } \\
\text { Growth Rate } \\
\text { (RGR) }\end{array}$ & $\begin{array}{c}\text { Current Revenue - previous } \\
\text { year's revenue/ previous } \\
\text { year's revenue }\end{array}$ & \\
\hline $\begin{array}{l}\text { CEO Tenure } \\
\text { (CEOT) }\end{array}$ & Intervening & Years & $\begin{array}{c}\text { Number of years since } \\
\text { appointment of a CEO- } \\
\text { NYSCEOA }\end{array}$ & $\begin{array}{c}\text { Murphy and } \\
\text { Zimmerman (1993) }\end{array}$ \\
\hline \multirow[t]{3}{*}{$\begin{array}{c}\text { Firms' } \\
\text { Characteristics }\end{array}$} & \multirow[t]{3}{*}{ Moderating } & Firms’ Size 1 & $\begin{array}{l}\text { The natural logarithm of total } \\
\text { assets }\end{array}$ & Barako et al., 2006 \\
\hline & & $\begin{array}{l}\text { Listed firms } \\
\text { (LIS) }\end{array}$ & $\begin{array}{l}\text { Dummy: } 1: \text { if institution is } \\
\text { listed on NSE; = 0: Otherwise }\end{array}$ & $\begin{array}{l}\text { Letting, Aosa and } \\
\text { Machuki (2012) }\end{array}$ \\
\hline & & $\begin{array}{l}\text { Ownership } \\
\text { structures } \\
\text { (OWN) }\end{array}$ & $\begin{array}{c}\text { Dummy: } 1: \text { if firm is state } \\
\text { owned; = 0: otherwise }\end{array}$ & $\begin{array}{l}\text { Elsayed (2007); } \\
\text { Ongeti (2014) }\end{array}$ \\
\hline
\end{tabular}

Author, 2017

\section{Data Analysis}

Descriptive statistics including measures of central tendency were calculated. Moderated and stepwise regression models and correlation analysis were adopted to investigate the association among board structure and performance. Some variables were denoted in logarithm form since they were measured in millions, while others were denoted as rates where the values were also high and the rest as absolute numbers. The usage of logarithm was to enhance standardization of values in the model.

The model tested hypothesis one as follows;

$\boldsymbol{R O A}_{i, t}=\alpha+\beta_{1} B S_{i, t}+\beta_{2} B C_{i, t}+\beta_{3} C E O D_{i, t}+\beta_{4} B A_{i, t}+\beta_{5} B D_{i, t}+\beta_{6} B T_{i, t}+$ $\varepsilon_{i, t} \ldots \ldots \ldots \ldots \ldots \ldots \ldots \ldots \ldots . . . . . .1 .1$ 
$R O A_{i, t}=\alpha+\beta_{1} B S_{i, t}++\beta_{2} B C_{i, t}+\beta_{3} C E O D_{i, t}+\beta_{4} B A_{i, t}+\beta_{5} B D_{i, t}+\beta_{6} B T_{i, t}$ $+\beta_{7} C E O T_{i, t t}+\varepsilon_{i, t \ldots . .1 .2}$

Where, ROA is Return on assets.

Board Structure is represented by; BS which is Board Size; BC is Board Composition; CEOD is Chief Executive Officer Duality; BA is Board Activity; BD is Board Diversity; and BT is Board Type. CEOT is Chief Executive Officer Tenure; $\alpha$ denotes the intercept, $\beta$ denotes the regression coefficient, and $\varepsilon$ denotes the error term.

The model tests hypothesis two as follows;

$\mathrm{ROA}_{i, t}=\alpha+\beta_{1} B S_{i, t}++\beta_{2} B C_{i, t}+\beta_{3} C E O D_{i, t}+\beta_{4} B A_{i, t}+\beta_{5} B D_{i, t}+\beta_{6} B T_{i, t}$ $+\beta_{7} C E O T_{i, t t}+\varepsilon_{i, t} \ldots \ldots . . .1 .3$

$\operatorname{RGR}_{i, t}=\alpha+\beta_{1} B S_{i, t}++\beta_{2} B C_{i, t}+\beta_{3} C E O D_{i, t}+\beta_{4} B A_{i, t}+\beta_{5} B D_{i, t}+\beta_{6} B T_{i, t}+$ $\beta_{7} C_{E O T} T_{i, t}+\varepsilon_{i, t} \ldots \ldots . . . .1 .4$

Where, CEOT is Chief Executive Officer Tenure, while the rest are as defined in Hypothesis one above.

The model tested hypothesis three as follows;

$\mathrm{ROA}_{i, t}=\alpha+\beta_{1} B S_{i, t}++\beta_{2} B C_{i, t}+\beta_{3} C E O D_{i, t}+\beta_{4} B A_{i, t}+\beta_{5} B D_{, t}+\beta_{6} B T_{i, t}+$ $\beta_{7} S I Z E 1_{i, t}+$ $\beta_{8} L I S_{i, t}+$

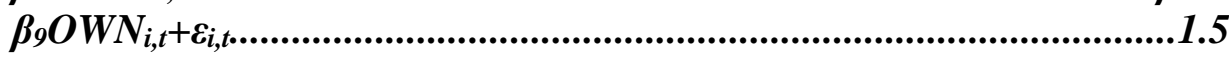
$R G R_{i,}=\alpha+\beta_{1} B S_{i, t}++\beta_{2} B C_{i, t}+\beta_{3} C E O D_{i, t}+\beta_{4} B A_{i, t}+\beta_{5} B D_{i, t}+\beta_{6} B T_{i, t}+$ $\beta_{7} S_{Z Z E} 1_{i, t}+$ $\beta_{9} L I S_{i, t+}$ $\beta_{10} O W N_{i, t}+$

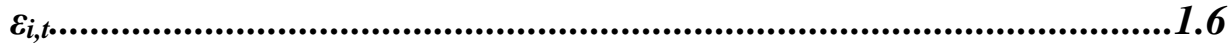

Where, Firms' Characteristics is represented by SIZE, LIS and OWN being Firms' Size, Stock exchange listing and Ownership Structure respectively. The other variables are as defined in hypothesis one above.

The model tested hypothesis four as follows;

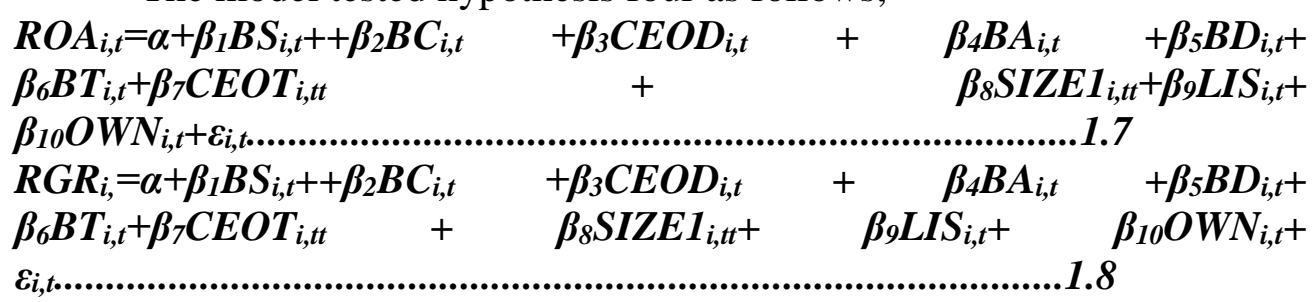

\section{Results}

\section{Correlation Analysis}

Correlation analysis using Pearson product moment correlation coefficient technique and partial correlation analysis was used to examine whether there exists an association among board structure, CEO tenure, firms' characteristics, and performance of organizations. Table 4.1 provides the findings of correlation analysis. The results demonstrate that there exists a statistical significant relationship among several board structure variables, CEO tenure, characteristics of the company, and performance of financial 
institutions in Kenya. These results provide additional confirmation of the hypothesis as formulated and are a necessary precondition for further statistical tests including regression and GEE performed on the study hypothesis.

Table 4.1. Correlation Analysis between Board Structure and Firms' Performance

\begin{tabular}{|c|c|c|c|c|c|c|c|c|c|}
\hline & & $\mathrm{ROA}$ & gSales & $\mathrm{NBM}$ & NIDOB & NBMeet & NFmDB & BoType & CEOT \\
\hline \multirow{3}{*}{ ROA } & Pearson Correlation & 1 & .136 & .033 & .238 & $-.298^{* *}$ & \begin{tabular}{|l|}
-.033 \\
\end{tabular} & $.407^{* *}$ & .153 \\
\hline & Sig. $(2-T)$ & & .231 & .773 & .096 & .008 & .773 & .000 & .177 \\
\hline & $\mathrm{N}$ & 79 & 79 & 79 & 50 & 79 & 79 & 79 & 79 \\
\hline \multirow{3}{*}{ gSales } & Pearson Correlation & .136 & 1 & .143 & .191 & -.038 & .175 & .033 & .163 \\
\hline & Sig. $(2-T)$ & .231 & & .208 & .184 & .738 & .124 & .776 & .150 \\
\hline & $\mathrm{N}$ & 79 & 79 & 79 & 50 & 79 & 79 & 79 & 79 \\
\hline \multirow{3}{*}{ NBM } & Pearson Correlation & .033 & .143 & 1 & $.812^{* *}$ & $436^{* *}$ & $.497^{* *}$ & $-.282^{*}$ & -.033 \\
\hline & Sig. (2-T) & .773 & .208 & & .000 & .000 & .000 & .012 & .775 \\
\hline & $\mathrm{N}$ & 79 & 79 & 79 & 50 & 79 & 79 & 79 & 79 \\
\hline \multirow{3}{*}{ NIDOB } & Pearson Correlation & .238 & .191 & $812^{* *}$ & 1 & .180 & $.429^{* *}$ & $.451^{* *}$ & .074 \\
\hline & Sig. (2-T) & .096 & .184 & .000 & & .211 & .002 & .001 & .610 \\
\hline & $\mathrm{N}$ & 50 & 50 & 50 & 50 & 50 & 50 & 50 & 50 \\
\hline \multirow{3}{*}{ NBMeet } & Pearson Correlation & $-.298^{* *}$ & -.038 & $.436^{* *}$ & .180 & 1 & $.280^{*}$ & $-.809^{* *}$ & $-.406^{* *}$ \\
\hline & Sig. (2-T) & .008 & .738 & .000 & .211 & & .013 & .000 & .000 \\
\hline & $\mathrm{N}$ & 79 & 79 & 79 & 50 & 79 & 79 & 79 & 79 \\
\hline \multirow{3}{*}{ NFmDB } & Pearson Correlation & -.033 & .175 & $.497^{* *}$ & $.429^{* *}$ & $.280^{*}$ & 1 & -.178 & .038 \\
\hline & Sig. (2-T) & .773 & .124 & .000 & .002 & .013 & & .117 & .741 \\
\hline & $\mathrm{N}$ & 79 & 79 & 79 & 50 & 79 & 79 & 79 & 79 \\
\hline \multirow{3}{*}{ BoType } & Pearson Correlation & $.407^{* *}$ & .033 & $-.282^{*}$ & $.451^{* *}$ & $-.809^{* *}$ & -.178 & 1 & $.461^{* *}$ \\
\hline & Sig. (2-T) & .000 & .776 & .012 & .001 & .000 & .117 & & .000 \\
\hline & $\mathrm{N}$ & 79 & 79 & 79 & 50 & 79 & 79 & 79 & 79 \\
\hline \multirow{3}{*}{ NYSCEOA } & Pearson Correlation & .153 & .163 & -.033 & .074 & $-.406^{* *}$ & .038 & $.461^{* *}$ & 1 \\
\hline & \begin{tabular}{|l|} 
Sig. (2-T) \\
\end{tabular} & .177 & .150 & .775 & .610 & .000 & .741 & .000 & \\
\hline & $\mathrm{N}$ & 79 & 79 & 79 & 50 & 79 & 79 & 79 & 79 \\
\hline
\end{tabular}

The strength of the association among board structure operationalized by the number of directors, number of independent board members, number of meetings held by board members, number of female directors and number of directors owning equity shares. Also, the firms' performance was determined using Pearson product moment correlation. As shown in Table $4.5 \mathrm{a}$ and $4.5 \mathrm{~b}$ above, there is a positive correlation among the structure of the board and performance variables which was statistically significant.

Similarly, partial correlation coefficients that indicate the linear association among structure of the board and profitability of financial institutions while controlling for the effects of CEO tenure were computed. All the variables are scale variables. The assumption is that two variables can have a perfect relationship, but if the association is not linear, a 
correlation coefficient is not a suitable statistic for determining their association. The basic question was: is there an association among board structure and performance of financial institutions in Kenya? What will be the relation if we control for CEO tenure? The study used three variable types; indicators of firm performance, ROA and growth in sales; indicators of board structure, Number of Board members (NBM), Number of independent directors on the board (NIDOB), Number of board meetings and other activities (NBMeet), Number of female directors on the board (NFmDB); and Board Type (BoType). The partial correlations tables below show both the zero-order correlations (correlations without any control variables) of all three variables and the partial correlation of the first two variables controlling for the influence of the third variable (CEO Tenure CEOT).

Table 4.2. Partial Correlations

\begin{tabular}{|c|c|c|c|c|c|}
\hline \multicolumn{6}{|c|}{$\begin{array}{l}\text { Number of Meetings (NBM) as board structure indicator and firms' performance of } \\
\text { financial institutions while controlling for the effects of CEO tenure. }\end{array}$} \\
\hline \multicolumn{3}{|c|}{ Control Variables } & $\mathrm{ROA}$ & NBM & CEOT \\
\hline \multirow{9}{*}{- none- $^{-a}$} & \multirow{3}{*}{ ROA } & Correlation & 1.000 & .033 & .153 \\
\hline & & Significance (2-tailed) & . & .773 & .177 \\
\hline & & Df & 0 & 77 & 77 \\
\hline & \multirow{3}{*}{ NBM } & Correlation & .033 & 1.000 & -.033 \\
\hline & & Significance (2-tailed) & .773 & & .775 \\
\hline & & Df & 77 & 0 & 77 \\
\hline & \multirow{3}{*}{ NYSCEOA } & Correlation & .153 & -.033 & 1.000 \\
\hline & & Significance (2-tailed) & .177 & .775 & \\
\hline & & Df & 77 & 77 & 0 \\
\hline \multirow{6}{*}{ NYSCEOA } & \multirow{3}{*}{ ROA } & Correlation & 1.000 & .038 & \\
\hline & & Significance (2-tailed) &. & .739 & \\
\hline & & Df & 0 & 76 & \\
\hline & \multirow{3}{*}{ NBM } & Correlation & .038 & 1.000 & \\
\hline & & Significance (2-tailed) & .739 & & \\
\hline & & Df & 76 & 0 & \\
\hline
\end{tabular}

The zero-order correlation between ROA and Number of Board members (NBM) as the board structure indicator, indeed, is both low $(0.333)$ and statistically insignificant $(\mathrm{p}<0.001)$. The partial correlation controlling for the effects of CEO tenure (CEOT), however, improved but is negligible $(0.038)$ and statistically not significant $(\mathrm{p}=0.739)$. The results therefore cannot lead to the conclusion that a relationship between ROA and Number of Board members (NBM) existed even after controlling for the effects of CEO tenure (CEOT). 


\section{Hypothesis Testing and Summary of Findings}

This was done through regression analysis. The regression was done through a panel process. Also, a number of alternatives of panel data hierarchical regressions were run, fixed and random effects, ordinary least squares commonly called OLS, generalized least squares (GLS), and a dynamic panel. Hierarchical multiple linear regression (HMLR) model was employed in assessing the nature of the relationship between various variables as hypothesised in the study at $5 \%$ level of statistical significance. Reliability tests on the regression models were then computed to determine the strength of the relationship among the variables. These tests included multicollinearity tests, adjusted coefficient of determination (adjusted R), Ftests, and $t$ tests. The data used in running the regression was the averages for all the 10 years per company.

The objective of the research centered on the establishment of the joint influence of board structure, CEO tenure, and firms' characteristics on performance of financial institutions in Kenya. Board structure was the independent variable. Furthermore, CEO tenure was conceptualized as an intervening variable, while firms' characteristics was conceptualized as a moderating variable in the board structure and performance of financial institutions in Kenya relationship. In order to effectively address the main research objective, four specific research objectives were formulated. The first objective was to ascertain the impact of board structure on profitability of financial institutions in Kenya. The second objective sought to examine the intervening effect of CEO tenure on the association among board structure and performance of financial institutions in Kenya. Similarly, the third objective was to establish the moderating impact of firms' characteristics on the association among board structure and performance of financial institutions in Kenya. The fourth objective sought to establish the combined influence of board structure, CEO tenure, and firms' characteristics on performance of financial institutions in Kenya. The board structure indicators used are the board size, board activity, board type, board diversity, board composition and CEO duality; while the performance variables used are ROA and growth in revenue; and the control variable is the CEO tenure and firms' characteristics measured by listing, firm's size, and ownership structures.

The study was anchored on agency theory, convergence-of-interests theory, entrenchment theory, upper echelons theory, and stewardship theory. Thus, it used positivistic philosophy in testing four quantitative hypotheses. The study hypothesized that structure of the board does not significantly affect profitability of financial institutions in Kenya; there is no significant intervening effect of CEO tenure in the association among board structure and performance; there is no significant moderating effect of institutional 
characteristics in the association among structure and performance; and there is no significant joint effect of board structure, CEO tenure and firms' characteristics on performance. Secondary data was collected from financial institutions in Kenya for a ten-year period from 2006 to 2015. The study used both a correlational descriptive research design and cross-sectional survey design. The data collected was subjected to correlation, generalized estimating equation (GEE) and regression analysis. The findings provided by these data analysis methods was to confirm bi-directional association among profitability and structure of the board of financial institutions in Kenya. This is in addition to confirming that CEO tenure and firms' characteristics impacted this relationship. The findings from the study on the impact of structure of the board on profitability of financial institutions brought out mixed results. The tests of hypotheses were done at 95 percent confidence levels $(\mathrm{p}<0.050)$ on the independent and combined effects. The results established that, over all, board structure had independent statistically significant impact on profitability of financial institutions in Kenya.

Hypothesis one (H01) hypothesized that there is no significant effect of board structure on profitability of financial institutions in Kenya. Results of hierarchical multiple regression show a significant impact $(p<0.05)$ of board structure on firms' performance. Similarly, the GEE results indicate that there is a significant effect $(p<0.05)$ of board structure on firms' performance and identifies board activity and board type as the two most statistically significant board structure variables that affect firms' performance. In general, it can therefore be concluded that there is a significant effect of board structure on profitability resulting in the rejection of null hypothesis one. The results further show that the optimal number of board of directors' meetings, and other activities that optimize performance of financial institutions in Kenya, are the 11 to 15 meetings in a year. Board type was also found to have a significant influence on performance of financial institutions in Kenya with board type 1 whose entire membership own equity shares being shown to have the greatest impact on performance of financial institutions in Kenya. The findings indicate that the other board structure variables including size, diversity, CEO duality, and independence do not significantly impact profitability of financial institutions in Kenya.

Hypothesis two (Ho2) sought to establish the intervening effect of CEO tenure on the association among board structure and performance of financial institutions in Kenya. Hypothesis two is not rejected implying that there is no significant intervening effect of CEO tenure in the association among board structure and performance of financial institutions in Kenya. Hypothesis three (H03) tested the mediating effect of firms' characteristics on the association among board structure and performance of financial institutions in Kenya. Results of this study indicate that board structure 
significantly predict firm's performance even when firms' characteristics is controlled $(\mathrm{p}<0.05)$, implying that firms' characteristics has a mediating association among board structure and performance of financial institutions in Kenya. The null hypothesis three is therefore rejected.

Hypothesis four (Ho4) assessed the joint effects of board structure, CEO tenure, and firms' characteristics on performance of financial institutions in Kenya. The findings of this study show that the overall model is statistically significant $(\mathrm{p}<0.05)$, implying that board structure, CEO tenure, and firms' characteristics jointly have a significant effect on performance of financial institutions in Kenya. The null hypothesis four is rejected.

\section{Conclusion}

The results presented mixed findings regarding the association among board structure variables and performance of financial institutions in Kenya. The intervening and moderating effect of CEO tenure and firm characteristics have also been documented. While several studies document a positive influence of board structure variables on performance, others found the opposite. This could be linked to the variety of methodologies and definitions of variables used and the study contextual factors that were not included in the analysis by the models used.

\section{References:}

1. Anderson, C. R. \& Reeb, M. D. (2004). Board Composition: Balancing Family Influence in S\&P 500 Firms. Administrative Science Quarterly, 49, 209-237.

2. Anderson, C., \& Anthony (1988). The new corporate directors. New York: John Wiley \& Sons.

3. Anthony Kyereboah-Coleman \& Nicholas Biekpe (2002). The Relationship between Board Size, Board Composition, CEO Duality and Firm Performance: Experience from Ghana.

4. Balta, M. E. (2008). The Impact of Business Environment and Boards of Directors on Strategic Decision - Making: A Case Study of Greek Listed Companies, Unpublished $\mathrm{PhD}$ Thesis, Brunei Business School.

5. Barako, D.G., Hancock, P., \& Izan, H. Y. (2006). Factors influencing voluntary corporate disclosure by Kenyan companies. Journal compilation, Blackwell Publishing Ltd, 14, 121-148.

6. Beasley, M. S. (1996). An Empirical Analysis of the Relation between the Board of Director Composition and Financial Statement Fraud. The Accounting Review, 71, 443-65. 
7. Beasley, M. S., Carcello, J. V., Hermanson, D. R., \& Lapides, P. D. (2000). Fraudulent Financial Reporting: Consideration of Industry Traits and Corporate Governance Mechanisms. Accounting Horizons, 14(4), 441-454.

8. Berle Adolf \& Means Gardiner (1932). The Modern Corporation and Private Property. McMillan, New York.

9. Black, B., H. Jang, \& Kim, W. (2003): Does Corporate Governance Affect Firm Value, Working paper 327, Stanford Law School

10. Coles, J.L., N.D. Daniel, \& Naveen, L. (2008). Boards: Does One Size Fit All? Journal of Financial Economics 87, 329-356.

11. Dahya, J. \& McConnell, J. J. (2007). Board Composition, Corporate Performance, and the Cadbury Committee Recommendation. Journal of Financial and Quantitative Analysis, 42(3), 535-564.

12. Daily, C. M. \& Dalton, D. R. (1994b), Bankruptcy and Corporate Governance: The Impact of Board Composition and Structures. Academy of Management Journal, 37 (6), 1603-1617.

13. Dalton, D. R., Daily; C. M., Ellstrand, A. E. \& Johnson, J. L. (1998). Meta-Analytic Review of Board Composition, Leadership Structure and Financial Performance. Strategic Management Journal, 19 (3), 269-290.

14. Dalton, D., \& Daily, C. (1999). What's wrong with having friends on the board? Across the Board, (March), 28-32.

15. Davis, J., Schoorman, F., \& Donaldson, L. (1997). Toward a stewardship theory of management. Academy of Management Review, 22, 20-47.

16. Donaldson, L. \& Davis, J. (1991). Returns. Australian Journal of Management, 16, 49-64.

17. Dwivedi, N \& Jain, A K. (2005). Corporate Governance and Performance of Indian Firms: The Effect of Board Size and Ownership. Employee Responsibilities and Rights Journal, 17, 161172.

18. Eisenhardt, K. M. (1989). Agency theory: An Assessment and Review. Academy of Management Review 14, 57-74.

19. Elsayed, K. (2007). Does CEO Duality Really affect Corporate Performance, Corporate Governance: An International Review, 15 (6), 1203-1224.

20. Fama, E. F. \& Jensen, M. C. (1983). Separation of ownership and control. Journal of Law and Economics, 26, 301-325.

21. Gompers, P., Ishii, J. L. \& Metrick, A. (2003). Corporate Governance and Equity Prices. Quarterly Journal of Economics 118, 107-155.

22. Gurusamy, P. (2017). Board Characteristics, Audit Committee and Ownership Structure Influence on Firm Performance of 
Manufacturing Firms in India. International Journal of Business and Economics Research. Vol. 6, No. 4, 2017, pp. 73-87. doi: 10.11648/j.ijber.20170604.16

23. Jensen, M. C \& Meckling, W. (1976). Theory of the Firm: Managerial Behaviour, Agency Costs, and Ownership Structure. Journal of Financial Economics, 3,305-350.

24. Jensen, Michael C., \& Kevin J. Murphy (1990). Performance pay and top-management incentives, Journal of Political Economy, 98, 225264.

25. Johl S.K, Kaur S., \& Cooper B.J. (2015). Board Characteristics and Firm Performance: Evidence from Malaysian Public Listed Firms, Journal of Economics, Business and Management. Vol. 3, No. 2.

26. Johnson, J., Daily, C., \& Ellstrand, A. (1996). Boards of directors: A review and research agenda. Journal of Management, 22, 409-438.

27. Kamaara, M. W., Gachunga, H. \& Waititu, A.G. (2013). The relationship between board of director characteristics and performance of commercial state corporations in Kenya. International Journal of Innovate Research and Studies, 2, (11), 124136.

28. Klapper, L.F \& Love, I. (2002): Corporate Governance, Investor Protection and Performance in Emerging Markets. World Bank Policy Research Paper 2818, April

29. Klein, A. (2002). Audit committee, board of director characteristics, and earnings management. Journal of Accounting and Economics, Vol. 33, 375-400.

30. Letting N., Aosa E., \& Machuki, V.N. (2012). Board diversity and performance of companies listed in Nairobi Securities Exchange. International Journal of Humanities and Social Science, 2(11), 172182.

31. Morck, R., Shleifer, A. \& Vishny, R.W. (1988). Management Ownership and Market Valuation: An Empirical Analysis. Journal of Financial Economics, 20, 293-315.

32. Murphy, Kevin J., \& Jerold L. Zimmerman (1993). Financial performance surrounding CEO turnover. Journal of Accounting and Economics, 16, 1-3, 273-315.

33. Murphy, Kevin J., \& Jerold L. Zimmerman (1993). Financial performance surrounding CEO turnover. Journal of Accounting and Economics, 16, 1-3, 273-315.

34. Nicholson, G. J. \& Kiel, G. C. (2007). Can directors impact performance: A case based test of three theories of corporate governance. Corporate Governance: An International Review, 15, 585-608. 
35. Ongeti, W.J. (2014). Organizational Resources, Corporate Governance and Performance of Kenyan State Corporations. University of Nairobi, Ph.D. Thesis (Unpublished).

36. Rashid, A. \& Lodh, S. (2008). The Influence of Ownership Structures and Board Practices on Corporate Social Disclosures in Bangladesh, in Uddin, S. and M. Tsamenyi (Eds).

37. Shleifer, A., \& Vishny, R.W. (1994). A survey of corporate governance. Journal of Finance, 52(2), 737-783.

38. Shleifer, A., \& Vishny, R.W. (1997). A survey of corporate governance. Journal of Finance, 52(2), 737-783.

39. Teresa, M. \& Joseph, W. (2011). Corporate governance and board equity Ownership. Emerald Group Publishing Limited. Turnover. Journal of Accounting and Economics 16, 273-31

40. Weisbach, M. (1988). Outside directors and CEO turnover. Journal of Financial Economics, 20, 431-460.

41. Wintoki, M. B., Linck, J. S. \& Netter, J. M. (2012). Endogeneity and the Dynamics of Internal Corporate Governance. Journal of Financial Economics, 105(3), 581-606.

42. Yermack, D. (1996). Higher Market Valuation of Companies with a Small Board of Directors. Journal of Financial Economics 40, 185211.

43. Zahra, S. A., \& Pearce, J. A. (1989). Boards of directors and corporate financial performance: A review and integrative model. Journal of Management, 15, 291-334. 